\title{
The Pursuit of Happiness: The Effect of Social Involvement on Life Satisfaction in Canada
}

\author{
Leila Mazhari * \\ The University of Victoria \\ leilamaz@uvic.ca
}

\begin{abstract}
A popular area of discussion within "happiness studies" across disciplines is the question of whether money can buy happiness. Contradictory findings have encouraged an ongoing debate and have kept the topic aflame among sociologists, economists, and psychologists. Recently, sociologists have branched out to consider other social factors that may bear a closer relationship to a person's level of happiness: marital status, religiosity, work and employment, to name a few. Using quantitative methods to analyze data from the 2005-2006 World Values Survey, this paper shows that social involvement and civic participation can promote happiness among Canadians. Statistical controls rule out potential confounding variables, which are based on past literature on happiness studies. The results suggest that social involvement does indeed promote happiness among Canadians; however, there are multiple factors that increase or decrease one's likelihood of being socially involved. Three major influencers were identified: affluence, education and religiosity.
\end{abstract}

Keywords: Happiness; life satisfaction; social involvement; civic participation; Canadian society

\section{INTRODUCTION}

$\mathrm{F}$ or thousands of years, philosophers have mused on happiness - where it comes from, and what it brings us. In more recent decades, researchers across disciplines have identified the numerous benefits of being happy. Happiness has been shown to increase our productivity (Vincent-Hoper, Muser, \& Janneck, 2013); happy people tend to have higher rates of workplace success (Boehm \& Lyubomirsky, 2008); and, happiness may protect against becoming mentally or physically ill (Veenhoven, 2008). For this reason, numerous researchers have become increasingly interested in the correlates of happiness.

Despite the growing interest, the vast majority of research has been conducted in the United States and there has not been any sociological happiness studies conducted on the Canadian population specifically. This is a serious gap, and many researchers have pointed to the difficulties associated with drawing conclusions about the Canadian population based on findings that were drawn from the American population. For example, The 2014 World Happiness Report (Helliwell, Layard, \& Sachs) revealed that while the United States ranks fifteenth in the world, Canada ranks fifth. Clearly there is a significant difference between the north side of the border and the south, and sociological research on happiness-related subjects must acknowledge this.

Aside from this geographical gap in the literature, there also exists a gap with regards to happiness and social involvement. Vinson and Ericson (2013) have explored the relationship

*I wish to express my sincerest thanks to Dr. Min Zhou and Dr. André Smith for their ongoing guidance and support over the past year. 
between happiness and activity within environmental and humanitarian organizations among Australians using data from World Values Survey conducted in 2011. They found that membership in humanitarian organizations is significantly associated with life satisfaction; however, involvement in environmental organizations did not reveal any significant correlation (Vinson \& Ericson, 2013). Though Vinson and Ericson's (2013) study might offer some insight, the only indicators used for measuring social involvement and civic participation were membership in humanitarian and environmental organizations; other categories of social involvement and civic participation were not explored.

In order to fill this gap, this research seeks to examine the effect of social involvement and civic participation on Canadians' level of life satisfaction. This study goes beyond the investigation of the general effect of social involvement and civic participation in elevating individuals' life satisfaction; it distinguishes different types of social organizations individuals may participate in. More specifically, this paper examines potentially differing effects of the following six types of social organizations: (1) churches or religious organizations, (2) sport or recreational organizations, (3) art, music or educational organizations, (4) political parties, (5) environmental organizations, and (6) humanitarian organizations. Using multiple indicators is one more step towards revealing what social organizations are particularly beneficial in increasing happiness.

This article will first review current literature for each of the correlates of happiness, followed by a discussion of seven research hypotheses. The data, variables and method are reviewed, followed by a summary of the results, and a brief discussion. A further analysis is also explored before conclusions are presented.

\section{The Correlates of Happiness and Research Hypotheses}

Before discussing the correlates of happiness, it is important to note that one issue that has plagued "happiness studies" is the conceptualization of happiness itself; the definition of happiness varies across different literatures - without a clear and consistent definition it can convey multiple meanings. The conceptualization confusion becomes even more problematic when researchers decide to homogenize "happiness" with other terms. Especially, happiness is often overlapped with "well-being," which can be evaluated both objectively (income, health, social ties) and subjectively (the feeling of overall life satisfaction) (Fave, Brdar, Freire, Vella-Brodrick, \& Wissing, 2010). The measurement of objective "well-being" is often seen as problematic or not useful, as a high level of objective well-being may not necessarily lead to high levels of self-reported happiness. To avoid this confusion in conceptualization, happiness is defined as the feeling of overall life satisfaction. According to existing literature, there are several potential correlates of happiness, including income, religiosity, marital status, gender, age, employment status, education, and health.

\section{Income and Happiness}

Easterlin (1994) showed that sharp rises in national income did not make people happier, but people with relatively higher income report slightly higher levels of happiness. This "Easterlin Paradox," which is often referenced in economic literatures, generated debate on possible explanations for these findings. The most popular explanation that has empirical support is the argument that individuals are most concerned about their income in relation to others (Clark et al., 2008; Clark \& Senik, 2010; Easterlin, 1995; Frank, 1999; Solnick \& Hemenway, 2005). In other words, if everyone gains an equal amount of income, it has no effect; however, if some gain income and others do not, the richer will be happier due to their higher position in relation to their peers. This phenomenon 
has been further explored in the field of psychology and sociology. Researchers in these disciplines have found that if people strive for a specific level of income with the assumption that it will bring them happiness, upon reaching their goal they are soon habituated and consequently strive for the next level of income (Csikszentmihalyi, 1999; Fischer, 2007). For this reason, Csikszentmihalyi (1999) noted that individuals can be caught in a never-ending pursuit (1999). Dunn and Norton (2013) explain the contradictions by taking a unique perspective: supported by their research findings, they present the argument that, although people cannot become happier from collecting wealth, they can achieve happiness from spending money - if (and only if) it is spent in the right way. According to their study, people report greater increases in their happiness levels when they buy something for someone else rather than themselves. People also reported higher increases in happiness when they bought something for an experience (such as concert tickets) rather than tangible items (such as shoes). Both factors indicate that there is indeed a social aspect to happiness (Dunn \& Norton, 2013).

\section{Religiosity and Happiness}

In addition to the relationship between income and happiness, research has been conducted to explore the relationship between people's religiosity and level of happiness. Using data from the General Social Survey, Ferriss (2002) examined the relationship between respondents' self-reported happiness and their attendance at religious services. He found that "the percentage of individuals who claimed to be "very happy" is lower for those who "never" attend religious services $(26.6 \%)$ than those who attend "more than once weekly," (46.6\%). In contrast, this pattern is not observed for the percentage of those that identified as "not too happy" (Ferriss 2002; 206). Despite this trend, there were still a significant number of respondents that reported themselves as being "very happy," yet never or seldom attend religious services (35.3\%). Ferriss (2002) concludes that "despite inconsistencies, the test of association shows a significant relationship... but obviously other influences are operating" (p. 206). In addition to Ferriss, Witter, Stock, Okun, and Haring (1985) looked at 28 studies that addressed religion and well-being, and found that there was a stronger relationship between the two variables among older than younger samples. This could be explained in part by results found by Cox and Hammonds (1988): over time, the place of worship "becomes the focal part of social integration and activity... providing them with a sense of community and well-being." Here we see the pattern continue: the social aspect of happiness.

\section{Marital Status, Gender, Age and Happiness}

Studies have consistently shown that married people are happier than those who are divorced, widowed, or have never been married. A national survey of approximately 35,000 Americans showed that while $40 \%$ of married adults reported being "very happy," only $26 \%$ of those who had never been married responded the same (Myers, 2000). Findings suggest that the reason behind this correlation runs deeper than the formal label: marriage can provide both partners with love, companionship and support (Myers, 2000). Within this area, researchers have uncovered that there are gender and age differences when it comes to marriage and its relationship to happiness. For example, the benefits of marriage mentioned (love, companionship and support) appear to have more emotional benefits for males than females, and serves as a protective factor for depression among the married men (Nolen-Hoeksema \& Rusting, 1999). Other research has found little or no gender difference in happiness or life satisfaction, but a strong divide seems to hold in the case of divorce: while more women experience depression, more men turn to alcohol abuse (Horwitz, White, \& Howell-White 1996). Such findings run consistent with Nolen-Hoeksema and Rusting's (1999) explanation for gender differences: "males are socialized not to experience or 
express affect as intensely as females" (p. 344). While males and females may experience the negative effects of separation in different ways or to different degrees, it remains clear that the happiness gap between married and unmarried people is approximately the same if you compare genders side-by-side (Myers, 2000).

\section{Employment Status and Happiness}

One's work status has also been shown to have an influence on a person's level of happiness, both at an immediate (disappointment, stress) and long-term (lower self-esteem) level (Clark \& Oswald, 1994; Wilson Walker, 1993). A longitudinal study that compared people's well-being before and after being laid-off made it clear that unhappiness was the direct result of becoming unemployed (Lucas, Clark, Georgellis, \& Diener, 2004). To support this further, research has shown that the opportunity to contribute to society can give people a sense of purpose, and thus increase people's life satisfaction (Clark \& Oswald, 1994).

\section{Education and Happiness}

Argyle (2001) did a comprehensive review that shows how one's level of education, which he defines as the number of years of schooling, has a positive relationship to a person's level of happiness. However, it appears that the level of education is not necessarily the endmost reason, but the stepping-stone towards having greater job satisfaction, as it generally provides more options for employment (Argyle, 2001). Cuñado and Pérez de Gracia's (2011) study in Spain controlled income and found that a positive relationship between education and happiness was indeed present, and their evidence suggested that education increases one's confidence or "selfestimation" from acquiring knowledge. Furthermore, Chen (2011) explored this relationship in China, Japan, Taiwan and South Korea, and found that those that receive higher education have larger social networks and have "greater involvement with the wider world" and, through those conditions, achieve higher levels of happiness. Thus, education enhances our ability to connect with the wider social world, which in turn makes us happier.

\section{Health and Happiness}

Researchers have found that there is a significant relationship between happiness and physical well-being, as well as longevity (Veenhoven, 2008). Empirical evidence also shows that a person's self-reported happiness is closely related to their perceived health status; at the same time, how happy a person feels has a significant impact on their health status (Borghesi \& Vercelli, 2012). Despite this, most studies identify life satisfaction as the dependent variable and self-perceived health as the independent variable; these studies have revealed that individuals with better self-perceived health report higher levels of life satisfaction (Garrido, Méndez, \& Abellán, 2013). Siahpush, Spittal, and Singh's (2008) study examined the opposite direction effect, finding that life satisfaction and happiness predicted self-perceived levels of health after a two-year follow-up. It is clear that happiness and health are related, and it appears that the nature of the relationship goes in both directions (Borghesi \& Vercelli, 2012). As noted by Diener and Sligman (2004), studying well-being and physical health is important to lead public health policy, and could potentially influence health care costs if it is effectively used in a preventative manner. 


\section{Social Involvement/Civic Participation and Happiness}

Putnam's (2001) work discusses how Americans have drifted apart since the 1950s; Americans now sign fewer petitions, belong to fewer organizations that meet in person, know their neighbours less, meet with friends less frequently, and socialize with families less often. Putnam (2001) describes how modern society has caused us to become increasingly disconnected from each other, and credits technological advances as playing a significant role in this decline of social involvement and civic participation.

However, the last ten years specifically have changed the shape and nature of our social lives exponentially; information and communication technologies (ICTs) are integrated into our everyday lives more than ever before (Haythornthwaite \& Kendall, 2010). Contrary to the headlines that tend to highlight the sense of loneliness that has followed this Internet era, much research has found that the Internet has actually positively affected relationships, as communication between friends and family that live far away from one another has improved (Bargh \& McKenna, 2004). On Skype we can "have tea" with one friend in Victoria, and then another in Bangkok minutes later. Now there is also an array of online petitions; more and more people are joining Internetbased activist groups, and people can provide or receive funding from those who support the same causes (i.e. gofundme.com). Social media websites, chat rooms, and forums have also provided a site of "meeting" those with shared interests (Bargh \& McKenna, 2004). Some research has reached the conclusion that the Internet is a site of community involvement where users can form and maintain meaningful relationships, which often spillover into "real life" (Bargh \& McKenna, 2004; Haythornthwaite \& Kendall, 2010). Mesch (2010) found that "the formation and active participation in local community electronic networks not only adds but also amplifies civic participation and elevates sense of community attachment" (p. 1197). Capece and Costa (2013) highlighted that the past two decades have been transformative: we now have "network communities" which differ from "online communities" because "they refer to a specific territory ... [and] serve as a social catalyst for the corresponding territorial community" (p. 438).

Davidson and Cotter (1991) explored the correlation between sense of community and subjective well-being and found that that there was a significant positive relationship. Those with a high sense of community appear to share certain characteristics: "they have a feeling of belongingness; they believe that they can exert some control over the group and also be influenced by the group; they believe that their needs can be and are being met through the collective capabilities of the group; and, because of a shared history, they feel a very strong emotional bonding and investment in the group" (Davidson \& Cotter, 1991:246). Horst and Coffé (2011) have examined the benefits of friendship networks, and how it can impact one's subjective well-being, friendship networks were found to promote more social trust, less stress, better health, and increased social support. The Horst and Coffé (2011) study also found that subjective well-being was significantly positively affected by frequent face-to-face contact with close friendship networks. Voluntary organizations that individuals participate in have their own unique social networks that, too, can influence one's life greatly. Researchers such as Frey (2008) found that those who volunteer on a regular basis report being happier and of better health than those who do not volunteer. Based on these research findings, I make the following hypothesis:

H1: social involvement and civic participation has a positive effect on the level of life satisfaction in Canada.

However, perhaps not all types of social organizations are equally beneficial—while participation in (1) a church or a religious organization, (2) sport or recreational organizations, (3) art, music 
or educational organizations, and (6) humanitarian organizations may promote life satisfaction, involvement in (4) political parties and (5) environmental organizations may potentially make individuals less satisfied with life.

\section{Participation in a Church or a Religious Organization}

As discussed in the "Religiosity and Happiness" section above, being a member of a church or a religious organization provides individuals with a close social circle that offers support and other aspects of social capital. Religious organizations often meet on a regular basis and many relationships that are developed within that community extend to other aspects of people's lives. For example, one family that meets another at church may get together outside of the religious setting and have dinner together, creating an even closer relationship between one another. These relationships may have an especially close bond since both parties share a common set of values, beliefs, and language. In addition to building these social bonds, being part of a church or a religious organization may provide people with a sense of belonging and purpose within a larger social context, fostering overall life satisfaction. For this reason, I make the following hypothesis:

H2: Being a member of a church or a religious organization has a positive effect on the level of life satisfaction in Canada.

\section{Participation in Sport or Recreational Organizations}

As with being part of a church or a religious organization, being a member of sport or recreational organizations may also provide people with a community that has close social ties. Similar too is that these organizations meet regularly and it is generally a long-term commitment (playing on a soccer team, for example). Growing both personally and as a team can foster a sense of solidarity and comradeship, while also giving people a feeling of accomplishment as goals are reached. Developing and keeping social ties, as well as reaching individual and team goals, can have a positive impact on people. Research has explored how physical activity on its own can contribute to individual's happiness - both momentary and long-lasting. Some studies have found that those who participate in regular physical activity report higher levels of subjective well-being than those who do not (Forrest \& McHale 2009; Huang \& Humphreys 2012). Such findings suggest that participating in sport or other leisure activities can contribute to happiness; when paired with being a member of a collective organization, it seems likely that it can positively affect a person's level of life satisfaction. To investigate this, I hypothesize the following:

H3: Being a member of sport or recreational organizations has a positive effect on the level of life satisfaction in Canada.

\section{Participation in Art, Music or Educational Organizations}

Members of art, music or educational organizations gain similar types of social bonds mentioned so far. Art and music organizations in particular tend to have close-knit communities, as they have a common appreciation for creative talent and often meet in social settings, such as a theatre performance or a gallery showing. Members of art and music organizations are often artists themselves, giving them a shared area of passion and interest. Contributing to the 
organization, whether it be art directly or as an audience, may provides regular and meaningful social relationships and interactions. Based on this observation, I hypothesize:

H4: Being a member of art, music or educational organizations has a positive effect on the level of life satisfaction in Canada.

\section{Participation in Political Parties}

While being a member of political parties surely creates a sense of community as well, it is likely that a significant number of these members are unsatisfied with the current government policies. Generally those who are heavily involved in politics hold very strong and specific political positions and therefore are drawn towards one specific party. While these members may gain short-term happiness if their particular party gains support and political power for a certain period of time, there is constant tension between parties, particularly around elections. Members of these organizations are likely to watch or read the news, which reports (for the most part) negative events taking place worldwide. This, surely, could cause frustration, distress and an overall sense of discontentment that may not have any attainable solution. For this reason, this study makes the following hypothesis:

H5: Being a member of political parties has a negative effect on the level of life satisfaction in Canada.

\section{Participation in Environmental Organizations}

Those who have a high level of concern regarding environmental degradation are likely to feel that they are fighting an uphill battle. Particularly in Canada, where there are few eco-sensitive government policies in place, environmental organization members, while having a community and sense of solidarity with one another, are likely to feel a sense of helplessness throughout their life course. Even the most optimistic members are unlikely to ever be satisfied, as goals are extremely difficult to reach in this area. Much irreversible damage to the environment has already been done, and one organization simply cannot repair the global environmental degradation. To investigate this, I make the following hypothesis:

H6: Being a member of environmental organizations has a negative effect on the level of life satisfaction in Canada.

\section{Participation in Humanitarian Organization}

Unlike members of environmental organizations, members of humanitarian organizations are much more likely to see progress and reach their goals. For example, a member of a humanitarian organization can actively make a difference by volunteering to build a school in a poor community. Their actions, both as individuals and as an organization, have a significant impact on the lives of others and they can see the difference they make right before their eyes. Even the most ambitious projects, such as putting an end to homelessness, can be extremely rewarding, since members can make a significant difference within a given community. Helping those in need provides a 
sense of purpose, accomplishment, and pride. It can be a very humbling experience and make a person extremely grateful for the resources and rights they have as Canadians. These factors surely impact how happy a person is, and their overall life satisfaction and, therefore, I make the following hypothesis:

H7: Being a member of humanitarian organizations has a positive effect on the level of life satisfaction in Canada.

\section{Data, Variables ANd Method}

\section{Data}

In order to test these seven hypothesis, the current study uses the Canadian data from the fifth wave of the World Values Survey (WVS), collected by the World Values Survey Association in 2006. A total of 2,164 individuals were asked to rate their level of life satisfaction, as well as their participation in various organizations.

\section{Variables}

\section{II.1 Dependent Variable}

The respondents' happiness is measured using the questionnaire item: "All things considered, how satisfied are you with your life as a whole these days?" It is measured on a scale of 1 to 10, with 1 being "completely dissatisfied" and 10 being "completely satisfied." Hence, a larger score indicates a higher level of satisfaction. This question was selected over the preceding question that asks the respondent to report their level of happiness, because the life satisfaction question makes clear that they are to consider their life as a whole, rather than a momentary feeling or emotion.

\section{II.2 Independent Variables}

Seven independent variables are examined, which measure the respondent's level of social involvement and civic participation. Six of the variables are taken directly from the World Values Survey: (1) a church or a religious organization, (2) sport or recreational organizations, (3) art, music or educational organizations, (4) political parties, (5) environmental organizations, and (6) humanitarian organizations. On the survey, each dimension is coded according to whether the respondent is an "active member," an "inactive member," or "not a member." The first two categories are combined ("active member" and "inactive member") as they both indicate membership. In other words, this study examines whether the respondent is a member or not, regardless if they are currently active. This is because one's membership in a humanitarian organization from 1993-1998, for example, can influence a person's overall life satisfaction, regardless of whether they are an active member at the time of the survey. Therefore, each variable is binary. Based on the six variables, a seventh independent variable is created: general social involvement. It is a composite one generated by summating the six specific variables, measuring the respondent's overall level of social involvement.

\section{II.3 Control Variables}

In order to rule out potential confounding influences, certain variables are held under control in the analysis. These variables were chosen based on findings in existing research, as presented in 
the literature review: (1) marital status; (2) religiosity; (3) gender; (4) age; (5) level of education; (6) employment status; (7) income level; (8) health. Table 1 in the Appendix presents the measurement of the variables that are controlled, while Table 2 presents basic descriptive statistics for the variables used in this analysis.

\section{METHOD}

The statistical modeling technique used is multivariate regression analysis. More specifically, ordinary least squares (OLS) multivariate regression analysis is used to assess the effect of social involvement and civic participation on Canadians' happiness, while holding the identified confounding variables under control. The regression equation is shown below:

$\mathrm{Y}=\beta_{0}+\beta_{1}$ Social $+\beta_{2}$ Marital $+\beta_{3}$ Religiosity $+\beta_{4}$ Gender $+\beta_{5}$ Age $+\beta_{6}$ Education $+\beta_{7}$ Employment $+\beta_{8}$ Income $+\beta_{9}$ Health $+\varepsilon$

$\mathrm{Y}$ is defined as the level of life satisfaction. $\beta_{0}$ is the intercept, $\varepsilon$ is the error term, and $\beta_{1}-\beta_{9}$ refer to the coefficients of social involvement and civic participation, marital status, religiosity, gender, age, education, employment status, income, and health, respectively.

In the analysis, social involvement and civic participation is measured in two ways: first, it is measured by the respondent's general social involvement and civic participation (i.e., a composite variable constructed from multiple indicators); second, it is measured more specifically by individual indicators (i.e. specific voluntary organizations). Accordingly, in the following analysis two separate analyses are used. The first analysis estimates the effect of general social involvement and civic participation on life satisfaction, while the second estimates the effects of being a member of the specific social organizations.

Within the first analysis (Table 3), three models are presented. Model 1 presents the effect of general social involvement on life satisfaction. Extending Model 1, Model 2 presents the effect of general social involvement with other control variables taken into account. To examine what variables have greater influences on life satisfaction, Model 3 reports the result of Model 2 using standardized coefficients. Different variables have differing units of measurement (e.g., age is measured in years, income is rated on a 11-point scale, etc.), and standardized coefficients standardize their units of measurement and thus allow for comparison across variables.

\section{Results And Discussion}

In this section, seven tables (Table 3 - Table 9) report the results of the data analysis; the results are then described and discussed in relation to the corresponding hypotheses.

Table 3 presents the effect of general social involvement on life satisfaction. At first glance, social involvement has a significant positive effect on Canadians' life satisfaction (Model 1). As individuals get more involved in social organizations, they are more satisfied with their life. This seems to be consistent with Hypothesis 1 . However, this effect becomes insignificant when other control variables are incorporated into the model (Model 2). Once those other variables are taken into account (namely, age, gender, marital status, level of education, employment status, income, level of health, and religiosity), that effect disappears. Significant effects are found in such variables as age, marital status, income, health, and religiosity. Specifically, in general older people are more satisfied with life than younger people. Those who are married report being happier than those who are not married. Canadians with higher levels of income are significantly happier. Those who are healthier report higher levels of life satisfaction than those less healthy. Lastly, those who are more religious are happier than those who are not religious. Gender, education and employment status do not have significant influences over Canadians' life satisfaction. Model 3 presents 
standardized coefficients. According to Model 3, the strongest predictor for life satisfaction among Canadians is their level of health, followed by marriage, income, age, and religiosity.

Hence, the data from the World Values Survey (WVS 2006) indicates that while social involvement and civic participation does have a significant effect on the level of life satisfaction amongst Canadians, its effect can be explained by such variables as age, marital status, income, health, and religiosity. Based on this finding, it appears that older, married, more affluent, healthier and more religious individuals are more likely to be socially involved and active in civic activities, thereby being happier than others.

Tables 4-9 present the effects of participation in different types of social organizations on life satisfaction. We can identify two patterns from the results and distinguish two groups of social organizations in terms of their effects on life satisfaction. The first group includes (1) a church or a religious organization and (3) art, music or educational organizations, while the second group includes (2) sport or recreational organizations, (4) political parties, (5) environmental organizations, and (6) humanitarian organizations.

Pattern 1. Being a member of (1) a church or a religious organization and (3) art, music or educational organizations appears to have a significant positive impact on Canadians' happiness (Model 1 in Table 4 and Table 6). In other words, it seems the more that people are involved in religious or art and education-related organizations, the more satisfied they are with their life. These results seem to support Hypotheses 2 and 4 . However, as with the previous table, once control variables are integrated (Model 2 in Table 4 and Table 6), the relationship disappears. Also consistent with the previous analysis, significant effects are found in marital status, income, health, and religiosity. Those who are married are happier than those unmarried; those with higher incomes are happier than those with lower incomes; healthier Canadians are happier than those less healthy; those that are more religious are happier than those who are not religious. Once again, it appears that gender, education and employment status do not have significant impacts on Canadians' levels of life satisfaction. Hence, the World Values Survey (WVS 2006) data suggests that being a member of religious organizations or art, music and educational organizations can increase one's level of life satisfaction; however, this effect may be explained by other variables (namely age, marital status, income, health, and religiosity). Older, married, more affluent, healthier and more religious individuals are more likely to be members of religious or art, music and educational organizations, and thus more satisfied with their life. As found with Hypothesis 1, when variables such as age, marital status, income, health, and religiosity are accounted for, the effect of a church or a religious organization membership disappears.

Pattern 2. Being a member of (2) sport or recreational organizations, (4) political parties, (5) environmental organizations, and (6) humanitarian organizations does not have a significant impact on Canadians' life satisfaction (Model 1 in Tables 5, 7, 8, and 9). Thus, Hypotheses 3, 5, 6, 7 are not supported by the empirical evidence here. However, Model 2 in these tables reveals that age, marital status, income, health, and religiosity all have significant effects - consistent with previous tables. Older Canadians are happier than those that are younger. Canadians that are married are happier than people that are unmarried. Those who are healthy report higher levels of life satisfaction that those that are less healthy. More religious Canadians are happier than those who are less religious or not religious at all. The other variables (gender, education and employment status) do not effect Canadians' life satisfaction significantly. Therefore, data from the World Values Survey (WVS 2006) reveals that being a member of sport or recreational organizations, political parties, environmental organizations, or humanitarian organizations does not have a significant effect on Canadians' life satisfaction, although other variables appear to bear a relationship. More specifically, those that are older, married, more affluent, healthier, and more religious may be more likely to report higher levels of life satisfaction. However, Canadians' 
membership to sport or recreational organizations, political parties, environmental organizations, or humanitarian organizations may not necessarily bring them more happiness than those that are not members.

\section{Further Analysis}

Overall, the data from the World Values Survey (WVS 2006) indicates that there are some significant relationships between Canadians' happiness and their general social involvement or their membership to certain organizations. However, the existing relationships disappear once other variables are controlled (namely age, marital status, income, health and religiosity). In order to have a deeper understanding of these findings, these control variables are examined to explain why Canadians participate, or not, in social activities in general, as well as the likelihood of Canadians being members of specific types of organizations. For general social involvement, OLS regression analysis is the chosen method of analysis and the result is presented in Table 10. For participation in social organizations, due to the binary nature of the variable (likelihood of being a member of a certain type of organization or not), logistic regression analysis is used and present the results in Table 11.

\section{I.1 Influences on General Social Involvement}

Religiosity holds the strongest relationship with Canadians being socially involved; religious Canadians are more involved socially than those that are not religious. Those who are members of a church or a religious organization build relationships with other members within that organization, creating community, belongingness, and so forth. In addition, Canadians that have higher levels of education are more socially involved than those with lower levels of education. This may be in part due to the networks that Canadians have access to through their education. For example, a Canadian that attends university builds a network of students and professors that are socially involved, and in turn become socially involved as well. More affluent individuals are more socially involved than those with lower incomes. Certain types of social involvement require financial means, so having a higher level of income allows certain individuals to be socially involved in ways that are simply impossible for those with lower incomes. Age, gender, employment status and one's level of health do not play a significant role in how socially involved Canadians are.

\section{I.2 Likelihood of Canadians Being Members of a Church or a Religious Organizations}

The only variable that has a significant influence over whether Canadians are members of a church or a religious organization or not is their level of religiosity. Those that are more religious are more likely to hold membership to a church or a religious organization. Age, gender, marital status, employment status, income and health are not significant determinants. There are many possible reasons for why such variables do not have a significant relationship with Canadians' membership. For example, income may not play a role since most religious organizations do not place a financial burden on their members.

\section{I.3 Likelihood of Canadians Being Members of Sport or Recreational Organizations}

Age, gender, education, income, health and religiosity are significantly correlated with Canadians' likelihood of being members of sport or recreational organizations. Younger and healthier Canadians are more likely to be members than older and less healthy Canadians. Young and 
healthy Canadians have an advantage over those that are older and less healthy, as it is generally physically demanding to be a member of these organizations. Males are also more likely to be members than females. Such findings imply that Canadian society encourages males to participate in these activities. Canadians with higher levels of education are also more likely to be members of sport or recreational organizations. Higher levels of education and religiosity can also influence Canadians' likelihood to be members; perhaps due to the networks formed in school and religious communities. In addition, many sport or recreational organizations are tied to educational institutions, and schools often encourage students to participate in such activities. Those that are more affluent are more likely to hold membership more often than those with lower incomes. Affluence makes it easier for Canadians to be active in these organizations, as some can be quite costly. Lastly, religious people tend to be more likely to be members of sport or recreational organizations than those that are not religious. Martial status and employment status, however, are not significantly related and thus cannot be thought of determinants.

\section{I.4 Likelihood of Canadians Being Members of Art, Music or Educational Organizations}

In Canada, people that are members of art, music or educational organizations are typically younger. Those with higher levels of education and higher incomes are also more likely to be members than those with less education and lower incomes. Canadians that hold higher levels of education are more likely to build personal relationships with those involved in these organizations since their networks are likely to cover a sphere of students pursuing art as either a profession or a hobby. Those with more education may also have more appreciation for art, music or educational organizations since they may have been exposed to such pieces during their school career. In addition, being a member of art, music or educational organizations often requires spending money (to attend plays or gallery showings, for example), so those that are more affluent are more likely to be inclined to be members of these organizations, relative to those that are on tighter budgets. Religiosity also bears a significant relationship with membership among Canadians. More specifically, religious Canadians are more likely to be members than those less or not religious. Those with higher religiosity may be members to these organizations since art, music and educational organizations sometimes incorporate religion itself. For example, a Christian artist may create paintings of Jesus; religious Canadians may be a member of a church choir; those who are more religious may participate in organizations that educate others on their religion and beliefs surrounding it. However, gender, marital status, employment status and health are not significant correlates.

\section{I.5 Likelihood of Canadians Being Members of Political Party Organizations}

Older Canadians are more likely to be members of political organizations. Life experience, combined with education and work experience, is likely to be tied to this older age group. Males are more likely to be members of political party organizations than females, and members tend to have higher levels of education. Since the beginning of political history in Canada, males have been overrepresented in political positions, and only recently have females entered the political realm. Thus, it is more likely for members to be male, since females have fewer figures to identify with and they are less likely to hold positions themselves. Political involvement also requires a certain degree of knowledge on political topics; higher levels of education typically provide and encourage this involvement, and schools teach students about political history and current events. Having more background knowledge surely gives educated Canadians more motivation to be involved in political party organizations than those with less education. Affluence also effects Canadians' likelihood of being members of political party organizations. Several reasons can 
explain this relationship. For example, those with higher incomes have a significant campaigning advantage over those with lower incomes. Lastly, religious Canadians are also more likely to be members of political party organizations than those that are not religious. Those who are religious may be more likely to be involved since political views are sometimes intertwined with religion. For example, Conservatives typically reflect their values and beliefs on their political policy preferences. Marital status, employment status and health do not have a significant relationship with whether Canadians are members of political party organizations or not.

\section{I.6 Likelihood of Canadians Being Members of Environmental Organizations}

The only identified variable that has a significant relationship with Canadians membership (or non-membership) to environmental organizations is their level of education. Specifically, those with higher levels of education are more likely to be involved than those with lower levels of education. This may be due to the fact that schools often raise awareness and encourage discussion around climate change and thus educated Canadians may have more environmental concern and seek out opportunities to make a difference. Age, gender, marital status, employment status, affluence, health and religiosity, on the other hand, do not significantly impact whether Canadians are members of environmental organizations or not.

\section{I.7 Likelihood of Canadians Being Members of Humanitarian Organizations}

Education levels, employment status, affluence and religiosity all have significant relationships with how likely Canadians are to be involved with humanitarian organizations. Those that have higher levels of education are more involved than those with less education. Educational institutions raise awareness of social justice and human rights issues across the globe. Therefore, the more education Canadians have, the more likely they are to want to be involved in humanitarian causes. Likewise, employment status can also change the likelihood of someone being a member of humanitarian organizations. Those that are employed are more likely to have the time and resources to "give back" to those that are in need of help; those that are unemployed, on the other hand, are typically on the receiving end, and do not have the means to help others. Canadians with higher incomes are more likely to be members than those with lower incomes. Since involvement (and membership) sometimes requires some financial investment, those with higher incomes are more likely to have money available for being members of these organizations. Lastly, religious Canadians are more likely to be involved than Canadians who are not religious. Religion often promotes bettering the living conditions of those less fortunate, as religious values and beliefs often stress the importance of equality and looking out for one another. Having these values engrained in those more religious may make religious Canadians more likely to be members of humanitarian organizations than those that are not religious. Age, gender, marital status and health do not significantly affect the likelihood of Canadians being members of humanitarian organizations.

\section{Summary ANd Conclusions}

\section{Limitations and Future Research Directions}

Although this article provided insight into the effect of social involvement and civic participation on Canadians' level of life satisfaction and distinguished between different types of social organizations individuals may participate in, this study encountered limitations that are important to note. Firstly, the analyses were based on data that was collected from the 2005-2006 World 
Values Survey; more updated data would have been ideal, but unfortunately the most recent wave (2014) did not include Canada. Second, the World Values Survey (WVS 2006) survey was cross-sectional. In the future, researchers should consider collecting data longitudinally in order to see whether Canadians' self-reported level of life satisfaction varies over time in relation to their social involvement and civic participation, or not. In other words, to isolate causality, researchers can examine whether a person's level of life satisfaction changes between when they are socially involved and when they are not (or vice versa). Further research should take multiple angles on this topic, examining both quantitative and qualitative data. Taking a quantitative approach to this topic on one hand made it possible to identify confounding variables that may have been overlooked if a quantitative study was done; however, there is a wealth of knowledge that simply cannot surface from a national survey. In-depth interviews could perhaps remedy this, uncovering various underlying meanings and connections. Researchers may also consider comparing membership to these organizations to other forms of social involvement (coffee dates, getting dinner with friends, etc.), and examine the similarities and differences. It would also be interesting to look at different definitions of social involvement, and where exactly the cyber-world fits into it. For example, is being part of an activist group on Facebook as rewarding as participating in an activist group that regularly meets face-to-face? Sociologists can examine happiness in relationship to social involvement in several directions that could help us understand our society better, and make way for better policy design.

There are two important conclusions that can be drawn from this study. First, it confirms the hypothesis that social involvement increases life satisfaction among Canadians; however, certain variables come into play that can make this relationship disappear. Second, it reveals factors that aid or hinder Canadians' likelihood of being socially involved. Three major influencers were identified: affluence, education and religiosity; in this section, these conclusions are elaborated on. Next, the contribution of this research to existing literature is reviewed, as well as policy suggestions.

At first glance, social involvement appears to have a significant impact on how happy Canadians are; those that are socially involved are more satisfied with their life than those that are less socially involved. Data collected by the World Values Survey (2006) suggests that older, married, more affluent, healthier and more religious Canadians are more socially involved, and thus happier than others. To have a better understanding of these results, a further analysis looked at what factors increase or decrease Canadians' likelihood of being socially involved and members of specific organizations. Several interesting findings emerged. Age bears a significant relationship with Canadians' likelihood to be members of certain organizations. More specifically, younger Canadians are more likely to be members in sport or recreational, or art, music or educational organizations, while older Canadians are more likely to be members of political party organizations. While younger Canadians have the time and energy to pursue more leisurely activities, political party organizations generally appeal to an older audience and often demand a degree of experience and education, which coincides with age. It also appears that membership to organizations is not necessarily dispersed evenly between females and males: rather, males are more likely to be members of sport or recreational or political party organizations. Although more and more women are pursuing these areas as time goes by, males are significantly more physically and politically active than females in Canada. Furthermore, married Canadians are no more likely to be socially involved in any particular organizations than those unmarried, and vice versa. However, education appears to play a key role in Canadians' social involvement and civic participation. More specifically, the more education that Canadians attain, the more likely they are to be involved in voluntary organizations- the only exception being a church or a religious organization. Healthy Canadians are more likely to be a member of a sport or recreational organization than those 
less healthy; however, health does not significantly influence one's membership to the other organizations. This, of course, has a circular effect: those that are healthy are more likely to join the organization in the first place, and their participation increases their health over time. Lastly, religiosity is significantly related to Canadians' involvement in all organizations, other than environmental organizations.

This research lends itself to policy implications and contributes to the gap in research regarding the effect of social involvement on Canadians' life satisfaction. It also sheds light on what makes them more or less likely to be socially involved. As we can see, social involvement does indeed increase happiness among Canadians; however, there are underlying reasons why Canadians are or are not members of certain organizations. In order to bring higher levels of life satisfaction to more Canadians, policies and programs must be implemented to aid certain individuals in their access to organizations to get them more socially involved. A Church or a religious organization and an art, music or educational organization appears to have the most significant influences on Canadians' happiness; therefore, it is recommended that they receive government attention in the future. On the other hand, while the other organizations did not have significant impacts on happiness among Canadians based on the data analyzed, they should not be disregarded.

Multiple policies and programs can encourage social involvement in Canada. For example, since these findings indicate that those with higher incomes are more likely to be a member of sport and recreational organizations, policy-makers should consider subsidizing membership fees for those with lower incomes. Tackling other inequalities in Canadian society may also increase overall life satisfaction among Canadians. For example, since the data revealed that males are much more involved in political party organizations than females, programs can be implemented to encourage female involvement and therefore increase their representation in the political realm. Since health is closely tied to life satisfaction among Canadians, policies could improve illness prevention and treatment. However, other areas, such as level of religiosity and age, are beyond the control of policy-making procedures. It is crucial to further study this topic, as there is currently very little research that provides opportunities for such policy changes. Many of these findings can shed light on the importance of certain aspects of Canadians' life satisfaction. This is a truly fascinating topic that deserves attention among Canadian researchers. Improving life satisfaction can benefit Canadians at both the individual and societal level and I encourage sociologists to investigate further.

\section{REFERENCES}

Argyle, M. (2001). The psychology of happiness. New York: Routledge. http://dx.doi.org/10.4324/9781315812212

Ball, R. J., \& Chernova, K. (2008). Absolute income, relative income, and happiness. Social Indicators Research, 88(3), 497-529. http://dx.doi.org/10.1007/s11205-007-9217-0

Bernhard, C. (2010). The relation between life satisfaction and the material situation: A reevaluation using alternative measures. Social Indicators Research, 98(3), 475-99. http://dx.doi.org/10.1007/s11205-009-9552-4

Borghesi, S., \& Vercelli, A. (2012). Happiness and health: Two paradoxes. Journal of Economic Surveys, 26(2), 203-33. http://dx.doi.org/10.1111/j.1467-6419.2010.00635.x

Clark, A. E., Frijters, P., \& Shields, M. A. (2008). Relative income, happiness, and utility: An explanation for the easterline paradox and other puzzles. Journal of Economic Literature, 46(1), 
95-144. http://dx.doi.org/10.1257/jel.46.1.95

Clark, A. E., \& Oswald, A. J. (1994). Unhappiness and unemployment. The Economic Journal, 104(424), 648-59. http://dx.doi.org/10.2307/2234639

Coffey, J. K., Wray-Lake,L., Mashek, D., \& Branand, B. (2014). A multi-study examination of well-being theory in college and community samples. Journal of Happiness Studies, 15(5), 1-26. http://dx.doi.org/10.1007/s10902-014-9590-8

Cox, H., \& Hammonds, A. (1988). Religiosity, aging, and life satisfaction.Journal of Religion and Aging, 5(1),1-21.

Csikszentmihalyi, M. (1999). If we are so rich, why aren't we happy?. American Psychologist. 54(10), 821-7. http://dx.doi.org/10.1037//0003-066x.54.10.821

Davidson, W. B., \& Cotter, P. R. (1991). The relationship between sense of community and subjective well-being: A first look.Journal of Community Psychology, 19(3), 246-53. http://dx.doi.org/10.1002/1520-6629(199107)19:3\%3C246::aid-jcop2290190308\%3E3.0.co;2-1

Diener, E. (2000). Subjective well-being: The science of happiness, and a proposal for a national index. American Psychologist, 55(1), 34-43. http://dx.doi.org/10.1037/0003-066x.55.1.34

Diener, E., \& Diener,C. (1996). Most people are happy. Psychological Science, 7(3), 181-5. http://dx.doi.org/10.1111/j.1467-9280.1996.tb00354.x

Dolan, P., Peasgood,T., White, M. (2008). Do we Really know what makes us happy? A review of the economic literature on the factors associated with subjective sell-being. Journal of Economic Psychology, 29(1), 94-122. http://dx.doi.org/10.1016/j.joep.2007.09.001

Dunn, E., Norton, M. (2013). Happy money: The science of smarter spending. New York: Simon \& Schuster.

Easterlin, R. A. (1973). Does money buy happiness? The Public Interest, 30(1), 3-11.

Easterlin, R. A. (1994). Will raising the incomes of all increase the happiness of all? Journal of Economic Behaviour E Organization, 27(1), 35-47. http://dx.doi.org/10.1016/0167-2681(95)00003-b

Fave, A. D., Brdar, I., Freire, T., Vella-Broadrick, D., \& Wissing, M. P. 2010. The eudaemonic and hedonic component of happiness: Qualitative and quantitative findings. Social Indicators Research, 100(2), 185-207. http://dx.doi.org/10.1007/s11205-010-9632-5

Ferris, A. L. (2002).Religion and the quality of life.Journal of Happiness Studies, 2(3), 199-215.

Frey, B. (2008). Happiness: A revolution in economics. London, England: MIT Press. http://dx.doi.org/10.7551/mitpress/9780262062770.001.0001

Garrido, S., Méndex, I., \& Abellán, J. (2013). Analysing the simultaneous relationship between life satisfaction and health-related quality of life.Journal of Happiness Studies, 14(6), 1813-38. http://dx.doi.org/10.1007/s10902-012-9411-x

Grant, D. (2010). Should happiness-maximization be the goal of government. Journal of 
Happiness Studies, 11(2), 163-78. http://dx.doi.org/10.1007/s10902-008-9129-y

Graham, C. (2009). Happiness around the world: The paradox of happy peasants and miserable millionaires. Oxford, UK: Oxford University Press. http://dx.doi.org/10.1093/acprof:osob1/9780199549054.001.0001

Headey, B., Ruud, M., and Wooden, M. (2007). Money does not buy happiness: Or does it? A reassessment based on the combined effects of wealth, income and consumption. Social Indicators Research, 87(1), 65-82. http://dx.doi.org/10.1007/s11205-007-9146-y

Horwitz, A. V., White, H. R., and Howell-White, S. (1996). Becoming married and mental health: A longitudinal study of a cohort of Young Adults. Journal of Marriage and Family, 58(4), 895-907. http://dx.doi.org/10.2307/353978

Horst, M., \& Coffé,H. (2012). How friendship network characteristics influence subjective well-being. Social Indicators Research, 107(3), 509-29. http://dx.doi.org/10.1007/s11205-011-9861-2

Kurdek, L. A. (1991). The relations between reported well-being and divorce history, availability of a proximate adult, and gender. Journal of Marriage and Family, 53(1), 71-8. http://dx.doi.org/10.2307/353134

Lim, C. \& Putnam,R. D. (2010). Religion, social networks, and life satisfaction. American Sociological Review, 75(6), 914-33. http://dx.doi.org/10.1177/0003122410386686

Lucas, R. E., Clark, A. E., Georgellis, Y., \& Diener, E. (2004). Unemployment alters the set point for life satisfaction. Psychological Science, 15(1), 8-13. http://dx.doi.org/10.1111/j.0963-7214.2004.01501002.x

Myers, D. G. (2000). The funds, friends and faith of happy people. American Psychologist, 55(1), 56-67. http://dx.doi.org/10.1037/0003-066x.55.1.56

Nolen-Hoeksema, S., \& Rusting,C. (1999). Gender differences in well-being. In D. Kahneman, E. Diener and N. Schwarz (Eds.), Foundations of hedonic psychology: Scientific perspectives on enjoyment and suffering. New York: Russell Sage Foundation.

Nolen-Hoeksema, S. \& Jackson, B. (2001). Mediators of the gender difference in rumination. Psychology of Women Quarterly, 25(1), 37-47. http://dx.doi.org/10.1111/1471-6402.00005

Phillips, D. L. (1967). Social participation and happiness. American Journal of Sociology, 72(5), 47988. http://dx.doi.org/10.1086/224378

Siahpush, M., Spittal, M., \& Singh, G. (2008). Happiness and life satisfaction prospectively predict self-rated health, physical health, and the presence of limiting, long-term health conditions. American Journal of Health Promotion, 23(1),18-26. http://dx.doi.org/10.4278/ajhp.061023137

Stutzer, A. (2004).The role of Income aspirations in individual happiness. Journal of Economic Behaviour E Organization, 54(1), 89-109. http://dx.doi.org/10.1016/j.jebo.2003.04.003

Tönnies, F. (1957). Community and society (Gemeinschaft und Gesellschaft). Loomis, C. P. (Ed.). New York: Harper \& Row. 
Putnam, R. (2001). Bowling alone: The collapse and revival of American community. New York: Simon \& Schuster.

Ura, K. (2012). A short guide to gross national happiness index. The Centre for Bhutan Studies 1-96.

Veenhoven, R. (2007). Healthy happiness: Effects of happiness on physical health and the consequences for preventive health care. Journal of Happiness Studies, 9(3), 449-69. $\mathrm{http} / / / \mathrm{dx}$.doi.org/10.1007/s10902-006-9042-1

Vinson, T. \& Ericson, M. (2013). The social dimensions and life satisfaction of australians: Evidence from the world values survey.International Journal of Social Welfare, 23(3), 240-53. http://dx.doi.org/10.1111/ijsw.12062

Wilson, S. \& Walker,G. (1993). Unemployment and Health: A Review. Public Health, 107(1),153-62. http://dx.doi.org/10.1016/s0033-3506(05)80436-6

Witter, R. A., Stock, W. A., Okun, M. A. \& Haring, M. J. (1985). Religion and subjective well-being in adulthood: A quantitative synthesis. Review of Religious Research, 26(4), 332-42. http://dx.doi.org/10.2307/3511048

World Values Survey (WVS) Association. (2009). WVS 2005-2008 Wave Official Data File. Retrieved November 17, 2014 (http:/ / www.worldvaluessurvey.org/). 


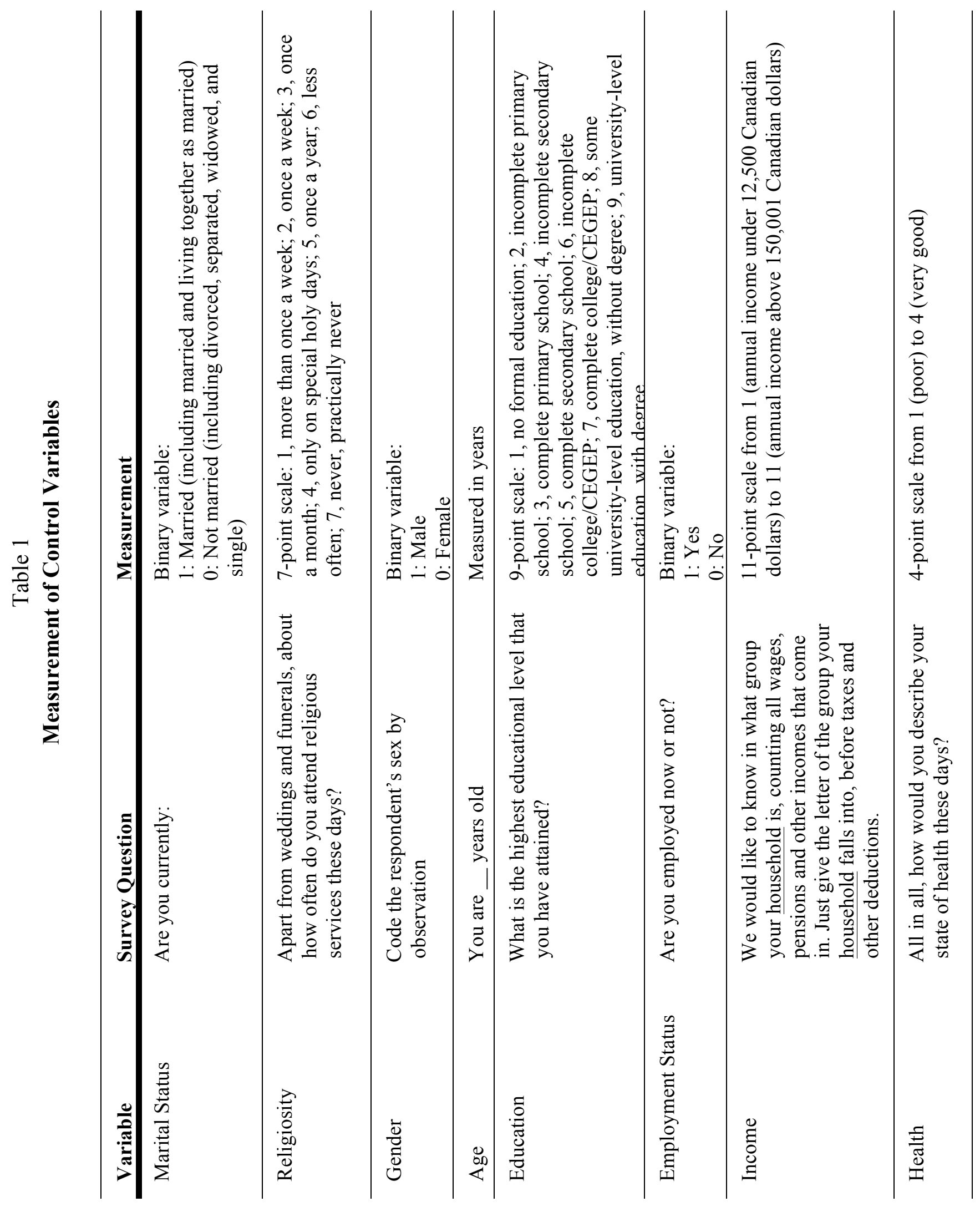


The Arbutus Review • Fall $2015 \bullet$ Vol. 6, No. 1

Table 2

Descriptive Statistics from the World Values Survey (WVS 2006)

\begin{tabular}{lcccc}
\hline Variable & Mean & SD & Minimum & Maximum \\
\hline Life satisfaction & 7.746 & 1.710 & 1 & 10 \\
Social involvement & 1.874 & 1.713 & 0 & 6 \\
Church or religious & .522 & .500 & 0 & 1 \\
Sport or recreational & .399 & .490 & 0 & 1 \\
Art, music or educational & .333 & .471 & 0 & 1 \\
Environmental & .151 & .358 & 0 & 1 \\
Humanitarian & .314 & .464 & 0 & 1 \\
Age & 48.211 & 17.801 & 16 & 94 \\
Gender (male) & .415 & .493 & 0 & 1 \\
Marital status & .619 & .486 & 0 & 1 \\
Education & 6.171 & 2.008 & 1 & 9 \\
Employment & .536 & .499 & 0 & 1 \\
Income & 5.634 & 2.947 & 1 & 11 \\
Health & 3.164 & .824 & 1 & 4 \\
Religiosity & 3.449 & 2.101 & 1 & 7 \\
\hline
\end{tabular}

Table 3

OLS Regression of Life Satisfaction in Canada, 2006

\begin{tabular}{llll}
\hline Variable & Model 1 & Model 2 & Model 3 \\
\hline Social involvement & $.042^{*}$ & -.008 & -.008 \\
& $(.022)$ & $(.024)$ & $(.024)$ \\
\hline Age & & $.010^{*}$ & $.101^{*}$ \\
& & $(.003)$ & $(.003)$ \\
\hline Male & -.137 & -.039 \\
& $(.078)$ & $(.078)$ \\
\hline Marital status & $.531^{*}$ & $.150^{*}$ \\
& & $(.084)$ & $(.084)$ \\
\hline Education & -.032 & -.038 \\
& & $(.022)$ & $(.048)$ \\
\hline Employment & .020 & -.006 \\
& & $(.092)$ & $(.092)$ \\
\hline Income & $.060^{*}$ & $.102^{*}$ \\
& & $(.016)$ & $(.016)$ \\
\hline Health & $.628^{*}$ & $.302^{*}$ \\
& & $(.048)$ & $(.048)$ \\
\hline Religiosity & $.055^{*}$ & $.066^{*}$ \\
& & $(.020)$ & $(.020)$ \\
\hline Constant & $4.677^{*}$ & $4.677^{*}$ \\
& & $(.243)$ & $(.243)$ \\
\hline
\end{tabular}

Notes: OLS, ordinary least squares. Numbers in parentheses are standard errors; from two-tailed tests, $* \mathrm{p}<.05$. 
The Arbutus Review • Fall $2015 \bullet$ Vol. 6, No. 1

Table 4

OLS Regression of Life Satisfaction in Canada, 2006

\begin{tabular}{lll}
\hline Variable & Model 1 & Model 2 \\
\hline Church or religious & $.142^{*}$ & -.015 \\
organization & $(.074)$ & $(.093)$ \\
\hline Age & $.010^{*}$ \\
& $(.003)$ \\
\hline Male & -.142 \\
& $(.078)$ \\
\hline Marital status & $.538^{*}$ \\
& $(.084)$ \\
\hline Education & -.031 \\
& & $(.022)$ \\
\hline Employment &,- 032 \\
& & $(.092)$ \\
\hline Income & $.058^{*}$ \\
& & $(.016)$ \\
\hline Health & $.624^{*}$ \\
& & $(.048)$ \\
\hline Religiosity & $.054^{*}$ \\
\hline Constant & $(.023)$ \\
\hline
\end{tabular}

Notes: OLS, ordinary least squares. Numbers in parentheses are standard errors; from two-tailed tests, ${ }^{*} \mathrm{p}<.05$.

Table 5

OLS Regression of Life Satisfaction in Canada, 2006

\begin{tabular}{lll}
\hline Variable & Model 1 & Model 2 \\
\hline Sport or recreational & .104 & -.062 \\
organization & $(.075)$ & $(.081)$ \\
\hline Age & $.010^{*}$ & $(.003)$ \\
\hline Male & -.138 \\
& & $(.078)$ \\
\hline Marital status & $.534^{*}$ \\
& $(.084)$ \\
\hline Education & -.030 \\
& & $(.022)$ \\
\hline Employment & -.036 \\
& & $(.092)$ \\
\hline Income & $.060^{*}$ \\
& & $(.016)$ \\
\hline Health & $.628^{*}$ \\
& & $(.048)$ \\
\hline Religiosity & $.053^{*}$ \\
\hline Constant & $(.019)$ \\
\hline
\end{tabular}

Notes: OLS, ordinary least squares. Numbers in parentheses are standard errors; from two-tailed tests, ${ }^{*} \mathrm{p}<.05$. 
The Arbutus Review • Fall $2015 \bullet$ Vol. 6, No. 1

Table 6

OLS Regression of Life Satisfaction in Canada, 2006

\begin{tabular}{lll}
\hline Variable & Model 1 & Model 2 \\
\hline Art, music or educational & $.173^{*}$ & .055 \\
organization & $(.045)$ & $(.085)$ \\
\hline Age & $.010^{*}$ & $(.003)$ \\
\hline Male & -.140 \\
& $(.078)$ \\
\hline Marital status & $.540^{*}$ \\
& $(.084)$ \\
\hline Education & -.036 \\
& & $(.022)$ \\
\hline Employment & -.032 \\
& & $(.092)$ \\
\hline Income & $.057^{*}$ \\
& & $(.016)$ \\
\hline Health & $.624^{*}$ \\
& & $(.048)$ \\
\hline Religiosity & $.050^{*}$ \\
\hline Constant & $(.019)$ \\
\hline
\end{tabular}

Notes: OLS, ordinary least squares. Numbers in parentheses are standard errors; from two-tailed tests, ${ }^{*} \mathrm{p}<.05$.

Table 7

OLS Regression of Life Satisfaction in Canada, 2006

\begin{tabular}{lll}
\hline Variable & Model 1 & Model 2 \\
\hline Political party & .002 & -.063 \\
organization & $(.010)$ & $(.104)$ \\
\hline Age & $.010^{*}$ \\
& $(.003)$ \\
\hline Male & -.135 \\
& $(.078)$ \\
\hline Marital status & $.540^{*}$ \\
& $(.084)$ \\
\hline Education & -.033 \\
& $(.022)$ \\
\hline Employment & -.027 \\
& & $(.092)$ \\
\hline Income & $.060^{*}$ \\
& & $(.016)$ \\
\hline Health & $.624^{*}$ \\
& & $(.048)$ \\
\hline Religiosity & $.053^{*}$ \\
& & $(.019)$ \\
\hline
\end{tabular}

Notes: OLS, ordinary least squares. Numbers in parentheses are standard errors; from two-tailed tests, ${ }^{*} \mathrm{p}<.05$. 
The Arbutus Review • Fall $2015 \bullet$ Vol. 6, No. 1

Table 8

OLS Regression of Life Satisfaction in Canada, 2006

\begin{tabular}{lll}
\hline Variable & Model 1 & Model 2 \\
\hline Environmental & -.033 & -.088 \\
organization & $(.752)$ & $(.107)$ \\
\hline Age & $.010^{*}$ & $(.003)$ \\
\hline Male & -.141 \\
& & $(.078)$ \\
\hline Marital status & $.531^{*}$ \\
& & $(.084)$ \\
\hline Education & $-.030^{*}$ \\
& & $(.022)$ \\
\hline Employment & -.030 \\
& & $(.092)$ \\
\hline Income & $.058^{*}$ \\
& & $(.016)$ \\
\hline Health & $.627^{*}$ \\
& & $(.048)$ \\
\hline Religiosity & $.052^{*}$ \\
& & $(.019)$ \\
\hline Constant & $7.751^{*}$ & $4.677^{*}$ \\
& $(.040)$ & $(.243)$ \\
\hline
\end{tabular}

Notes: OLS, ordinary least squares. Numbers in parentheses are standard errors; from two-tailed tests, ${ }^{*} \mathrm{p}<.05$.

Table 9

OLS Regression of Life Satisfaction in Canada, 2006

\begin{tabular}{lll}
\hline Variable & Model 1 & Model 2 \\
\hline Humanitarian & .134 & .011 \\
organization & $(.080)$ & $(.085)$ \\
\hline Age & $.010^{*}$ \\
& & $(.003)$ \\
\hline Male & -.143 \\
& $(.078)$ \\
\hline Marital status & $.534^{*}$ \\
& $(.084)$ \\
\hline Education & -.034 \\
& & $(.022)$ \\
\hline Employment & -.037 \\
& & $(.092)$ \\
\hline Income & $.059^{*}$ \\
& & $(.016)$ \\
\hline Health & $.624^{*}$ \\
& & $(.048)$ \\
\hline Religiosity & $.050^{*}$ \\
& & $(.019)$ \\
\hline
\end{tabular}

Notes: OLS, ordinary least squares. Numbers in parentheses are standard errors; from two-tailed tests, ${ }^{*} \mathrm{p}<.05$. 
The Arbutus Review • Fall $2015 \bullet$ Vol. 6, No. 1

Table 10

OLS Regression of Social Involvement in Canada, 2006

\begin{tabular}{lll}
\hline Variable & Model 1 & Model 2 \\
\hline Age & -.004 & -.046 \\
& $(.003)$ & $(.003)$ \\
\hline Male & .121 & .035 \\
& $(.076)$ & $(.076)$ \\
\hline Marital status & -.097 & -.028 \\
& $(.083)$ & $(.083)$ \\
\hline Education & $.159^{*}$ & $.188^{*}$ \\
& $(.021)$ & $(.021)$ \\
\hline Employment & .067 & .020 \\
& $(.090)$ & $(.090)$ \\
\hline Income & $.074^{*}$ & $.128^{*}$ \\
& $(.016)$ & $(.016)$ \\
\hline Health & .046 & .022 \\
& $(.047)$ & $(.047)$ \\
\hline Religiosity & $.254^{*}$ & $.313^{*}$ \\
& $(.019)$ & $(.019)$ \\
\hline Constant & -.327 & \\
\hline
\end{tabular}

Notes: OLS, ordinary least squares. Numbers in parentheses are standard errors; from two-tailed tests, ${ }^{*} \mathrm{p}<.05$. 


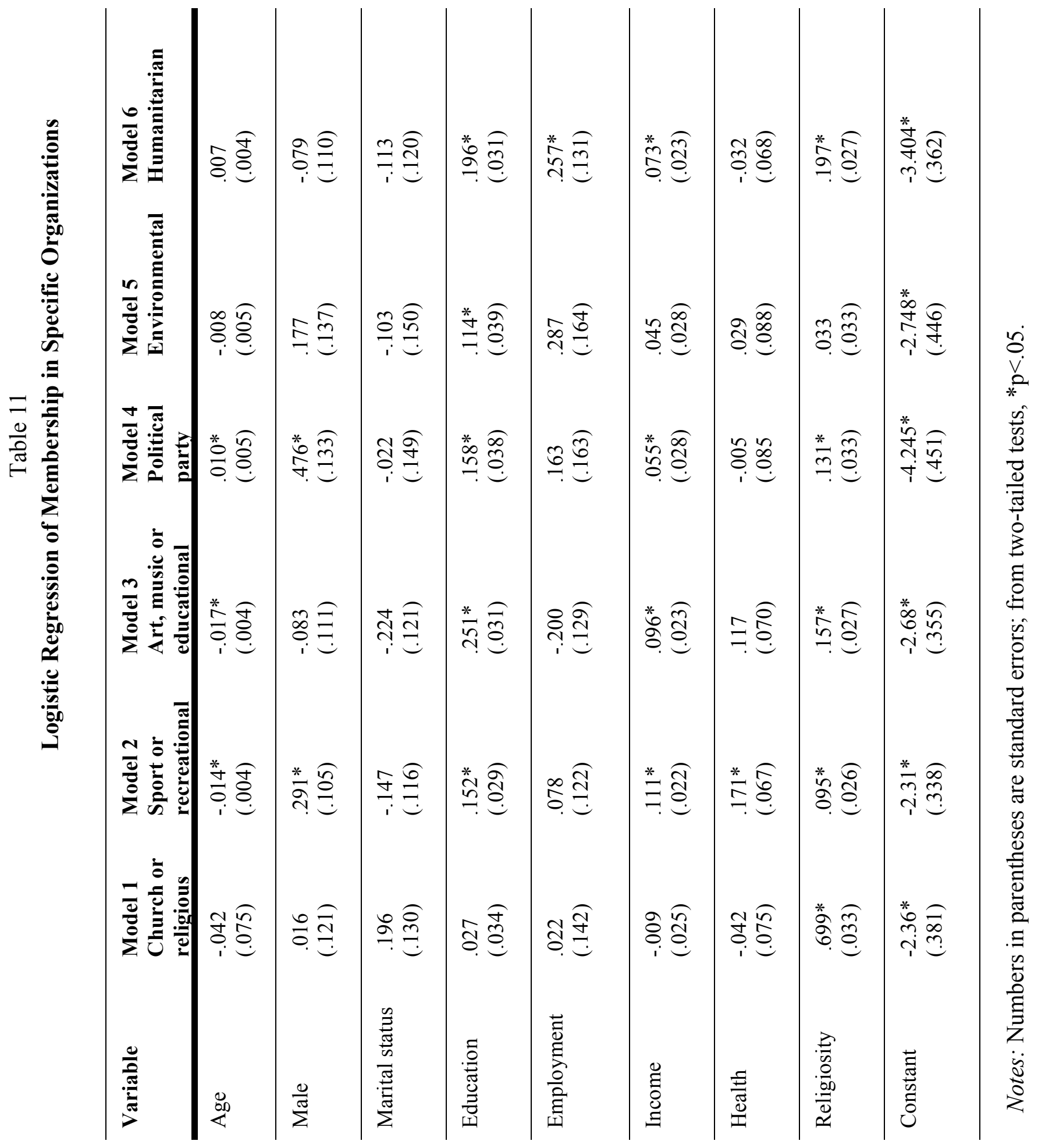

